\title{
Influence of drinking water salinity on carcass characteristics and meat quality of Santa Inês lambs
}

\author{
Daniela P. V. Castro ${ }^{1}$ - Sandra M. Yamamoto ${ }^{1}$ - Gherman G. L. Araújo ${ }^{2}$. \\ Rafael S. B. Pinheiro ${ }^{3}$ - Mario A. A. Queiroz ${ }^{1}$ - Ítalo R. R. Albuquerque ${ }^{4}$. \\ José H. A. Moura ${ }^{5}$
}

Received: 27 May 2016 / Accepted: 18 April 2017 / Published online: 10 May 2017

(C) Springer Science+Business Media Dordrecht 2017

\begin{abstract}
This study aimed to evaluate the effects of different salinity levels in drinking water on the quantitative and qualitative characteristics of lamb carcass and meat. Ram lambs $(n=32)$ were distributed in a completely randomized design with four levels of salinity in the drinking water (640 $\mathrm{mg}$ of total dissolved solids (TDS)/L of water, $3188 \mathrm{mg}$ TDS/L water, $5740 \mathrm{mg}$ TDS/L water, and $8326 \mathrm{mg}$ TDS/L water). After slaughter, blending, gutting, and skinning the carcass, hot and biological carcass yields were obtained. Then, the carcasses were cooled at $5{ }^{\circ} \mathrm{C}$ for $24 \mathrm{~h}$, and then, the morphometric measurements and the cold carcass yield were determined and the commercial cuts made. In the Longissimus lumborum muscle color, water holding capacity, cooking loss, shear force, and chemical composition were determined. The yields of hot and cold carcass (46.10 and $44.90 \%)$, as well as losses to cooling $(2.40 \%)$ were not affected $(P>0.05)$ by the salinity levels in the water ingested by the lambs. The meat shear force was $3.47 \mathrm{~kg} / \mathrm{cm}^{2}$ and moisture,
\end{abstract}

Sandra M. Yamamoto

sandra.yamamoto@univasf.edu.br

Daniela P. V. Castro

danipionorio_zootecnia@hotmail.com

Gherman G. L. Araújo

gherman.araujo@embrapa.br

Rafael S. B. Pinheiro

rafaelsbp@hotmail.com

Mario A. A. Queiroz

mario.queiroz@univasf.edu.br

Ítalo R. R. Albuquerque

italoreneu@hotmail.com crude protein, ether extract, and ash were 73.62, 22.77, 2.5 , and $4.3 \%$, respectively. It is possible to supply water with salinity levels of up to $8326 \mathrm{mg} \mathrm{TDS} / \mathrm{L}$, because it did not affect the carcass and meat characteristics of Santa Inês lambs.

Keywords Meat $\cdot$ Salt $\cdot$ Semi-arid $\cdot$ Sheep $\cdot$ Watering

\section{Introduction}

The climate conditions in the semi-arid region of northeast Brazil cause considerable impact on the sheep meat production, since low rainfall, high temperatures, exposure to high solar radiation, and high rates of evapotranspiration (ANA 2010), directly influence the production of food.

In addition to affecting the forage species production, the climatic peculiarity of this semi-arid northeast region affects the availability of quality water for animal consumption in

José H. A. Moura

josehelder_ztc@hotmail.com

1 Animal Science Department, Federal University of Vale do São Francisco, Petrolina, PE 56300-000, Brazil

2 Embrapa Semiárido, Petrolina, PE 56302-970, Brazil

3 Ilha Solteira School of Engineering, Biology Department, São Paulo State University, Ilha Solteira, SP 15385-000, Brazil

4 Federal University of Bahia, Salvador, BA 40170-110, Brazil

5 College of the Amazônia Reunida (FESAR), Redenção, PA 69550-325, Brazil 
certain times of the year, being the drinking water available targeted to human use.

The groundwater found in the this northeast region of Brazil, due to the geological characteristics of the semi-arid, present a wide variation, with different mineral concentrations varying from 0.00002 decisiemens per meter $(\mathrm{dS} / \mathrm{m})$ or $0.0128 \mathrm{mg}$ total dissolved solids (TDS) $/ \mathrm{L}$ to $75 \mathrm{dS} / \mathrm{m}$ or $48,000 \mathrm{mg}$ TDS/L of water (CPRM 2012), with very saline water and unfit for human consumption. However, these waters can be used for watering animals during periods of scarcity. It is necessary to know to what concentrations of salts the sheep can ingest, without affecting their health, performance, and the quality of their products.

Sheep can drink this water for their watering, but it is not known for sure how much these salinity levels can negatively influence them. There are a few scientific reports about the salinity effects on the qualitative parameters of the lamb meat. According to Colacelli (1997), the animals do not use or use little water with high salinity level, in which water with electrical conductivity between 8.0 and $11.0 \mathrm{dS} / \mathrm{m}$ has a limited use for some animals. The same author affirmed that animals that consume water of high salinity level could affect their meat quality, to the point of making it unsuitable for human consumption, becoming necessary further studies to show the high salinity water effects on the quantitative and qualitative characteristics of the carcass of sheep meat.

Given the above, this study had as objective to measure the effects of water consumption with different salinity levels on the carcass characteristics and meat quality of the Santa Inês lamb.

\section{Material and methods}

The study was developed in the Department of Animal Metabolism Embrapa Semiarido, in Pernambuco, Brazil, located at latitude $9^{\circ} 23^{\prime} 55^{\prime \prime} \mathrm{S}$ and longitude $40^{\circ} 30^{\prime} 03^{\prime \prime} \mathrm{W}$, with an average altitude of $365 \mathrm{~m}$ and annual rainfall of $300 \mathrm{~mm}$.

Thirty-two Santa Inês lambs, non-castrated, aged between 7 and 11 months, and initial body weight of $21.76 \pm 1.25 \mathrm{~kg}$, were used. The animals were housed in individual pens, provided with feeders and drinkers, receiving feeding composed of Buffel grass hay (Cenchrus ciliaris) and corn-based concentrate, soybean meal, and vitamin and mineral core, with roughage: concentrate ratio of 50:50, provided ad libitum. The ration was formulated according to the NRC requirements (2007) for lambs with up to $200 \mathrm{~g}$ /day gains (Table 1).

The treatments consisted of four levels of salinity of drinking water: $\mathrm{T} 1-640 \mathrm{mg}, \mathrm{T} 2-3188 \mathrm{mg}, \mathrm{T} 3-5740 \mathrm{mg}$, and T4 $-8326 \mathrm{mg}$ TDS/L of water, respectively, representing also electrical conductivity of $1,5,9$, and $13 \mathrm{dS} / \mathrm{m}$, respectively, with eight repetitions in a completely randomized design. The conversion of electrical conductivity to parts per million or in
Table 1 Chemical composition of feed ingredients consisting of Buffel grass hay and concentrate

\begin{tabular}{lcc}
\hline Components $^{\mathrm{a}}(\%)$ & Buffel grass hay & Concentrate \\
\hline $\mathrm{DM}$ & 85.20 & 84.90 \\
$\mathrm{OM}$ & 88.30 & 93.50 \\
$\mathrm{MM}$ & 11.70 & 6.50 \\
$\mathrm{CP}$ & 4.81 & 21.20 \\
$\mathrm{EE}$ & 1.31 & 2.54 \\
$\mathrm{NDFcp}$ & 71.87 & 17.50 \\
$\mathrm{ADF}$ & 47.90 & 4.83 \\
$\mathrm{TC}$ & 82.20 & 73.30 \\
$\mathrm{NFC}$ & 7.07 & 57.80 \\
\hline
\end{tabular}

${ }^{\text {a }} D M$ dry matter, $O M$ organic matter, $M M$ mineral matter, $C P$ crude protein, $E E$ ether extract, $N D F c p$ neutral detergent fiber corrected for ash and protein, $A D F$ acid detergent fiber, $T C$ total carbohydrates, NFC non-fiber carbohydrates

milligrams per liter multiplied by 640 , i.e., $1 \mathrm{dS} / \mathrm{m}$ is equivalent to approximately $640 \mathrm{mg} / \mathrm{L}$ or $640 \mathrm{ppm}$ (fresh water) according with Australian Water Association (2000).

For this experiment, we considered the control group containing $1 \mathrm{dS} / \mathrm{m}$ (minimum acceptable salinity, where the fresh water is considered). The treatments were thought about the salinity levels of the water offered to the sheep according to levels of acceptability mentioned in the Australian and New Zealand Guidelines for Fresh and Marine Water Quality (Australian Water Association 2000).

The salinities of the waters were obtained by adding sodium chloride $(\mathrm{NaCl})$, without iodine, in four water boxes containing fresh water available in the experimental field. Daily, conductivity, $\mathrm{pH}$, and temperature readings were taken for each treatment with a conductivity meter, allowing a difference of $5 \%$ of the limit of each treatment (Table 2).

The experiment lasted 73 days, in which 10 days were taken so that the animals could adapt to diets and facilities. At the end of the trial period, the animals were weighed to obtain the body weight (BW). Then, they were transported to the Federal Institute of Education, Science and Technology (IF-Sertão Pernambucano) where, after a fasting of solid food for $16 \mathrm{~h}$, they were weighed again, obtaining the body weight at slaughter (BWS), for subsequent calculation of the percentage of fasting loss $(\mathrm{FL})$ using the equation $\mathrm{FL}(\%)=[(\mathrm{BW}-\mathrm{BWS}) / \mathrm{BW}] \times 100$.

The animals were stunned by brain concussion, then bleeding, skinning, and gutting of carcasses were preformed, with subsequent weighing of full and empty gastrointestinal tract to obtain the weight of gastric contents (WGC) and the empty body (EB). Next, the carcasses were weighed (the hot carcass weight $(\mathrm{HCW})$; to determine the hot carcass yield $(\mathrm{HCY}(\%)=[(\mathrm{HCW} / \mathrm{BWS}) \times 100]$ and the real or biological yield $(\mathrm{RY}(\%)=[(\mathrm{HCW} / \mathrm{EB}) \times 100]$.

The carcasses were transferred to a cooling chamber at $5{ }^{\circ} \mathrm{C}$ and maintained for a period of $24 \mathrm{~h}$, when they were weighed 
Table 2 Values of conductivity, total dissolved solids (TDS), $\mathrm{pH}$, temperature, sodium $(\mathrm{Na})$, chloride, calcium $(\mathrm{Ca})$, magnesium $(\mathrm{Mg})$, potassium (K), and alkalinity of waters offered for Santa Inês lambs

\begin{tabular}{|c|c|c|c|c|}
\hline \multirow[b]{2}{*}{ Variables } & \multicolumn{4}{|c|}{ Treatment $^{\mathrm{a}}$} \\
\hline & 640 & 3188 & 5740 & 8326 \\
\hline Conductivity $(\mathrm{dS} / \mathrm{m})$ & 1.00 & 4.98 & 8.97 & 13.01 \\
\hline TDS (g/l) & 0.64 & 3.18 & 5.74 & 8.32 \\
\hline $\mathrm{pH}$ & 8.02 & 8.09 & 8.09 & 8.11 \\
\hline Temperature $\left({ }^{\circ} \mathrm{C}\right)$ & 25.60 & 25.15 & 24.70 & 24.86 \\
\hline $\mathrm{Na}(\mathrm{mg} / \mathrm{L})$ & 230.00 & 805.00 & 1725.00 & 2415.00 \\
\hline Chloride (mg/L) & 490.72 & 1898.34 & 2892.72 & 4519.87 \\
\hline $\mathrm{Ca}(\mathrm{mg} / \mathrm{L})$ & 17.56 & 23.04 & 27.41 & 36.02 \\
\hline $\mathrm{Mg}(\mathrm{mg} / \mathrm{L})$ & 12.51 & 18.48 & 24.86 & 26.23 \\
\hline $\mathrm{K}(\mathrm{mg} / \mathrm{L})$ & 2.71 & 3.32 & 3.52 & 4.10 \\
\hline Alkalinity (mg/L) & 30.40 & 29.45 & 27.00 & 31.20 \\
\hline
\end{tabular}

${ }^{\mathrm{a}}$ Treatments: $\mathrm{T} 1=640 \mathrm{mg}$ TSD in the water $(1 \mathrm{dS} / \mathrm{m}) ; \mathrm{T} 2=3188 \mathrm{mg}$ TSD in the water $(5 \mathrm{dS} / \mathrm{m}) ; \mathrm{T} 3=5740 \mathrm{mg}$ TSD in the water $(9 \mathrm{dS} / \mathrm{m})$, and $\mathrm{T} 4=8326 \mathrm{mg} \mathrm{TSD}$ in the water $(13 \mathrm{dS} / \mathrm{m})$

again in order to obtain the cold carcass weight (CCW); when calculating the cold carcass yield $(\mathrm{CCY}(\%)=$ $[(\mathrm{CCW} / \mathrm{BWS}) \times 100]$, that is, the losses by cooling $(\mathrm{CL}(\%)=[(\mathrm{HCW}-\mathrm{CCW}) / \mathrm{HCW}) \times 100]$.

After cooling, measurements for internal and external carcass lengths, leg length, and rump width were obtained, and then, the carcass and leg compactness indices were calculated. They are the relationships between the cold carcass weight and its internal length and between the rump width and the leg length, respectively.

The carcasses were divided longitudinally into two halfcarcasses, being the left side sectioned into six anatomical regions: neck, shoulder, rib, loin, leg, and low, according to a methodology adapted from Colomer-Rocher et al. (1987).

Subsequently, the loin was dissected, separating the longissimus lumborum muscle that was divided into two equal portions and frozen. Then, one of these portions was led to the Technology Laboratory of Animal Products of the Engineering School of Ilha Solteira (Unesp), to carry out the physical analysis of meat quality.

Meat samples were defrosted in a refrigerator for $24 \mathrm{~h}$ under a temperature of $6{ }^{\circ} \mathrm{C}$ to perform the analyses of color, water retention capacity (WRC), cooking losses (CL), losses by fat drip (FDL), by evaporation (EL), and shear force (SF).

The meat color was determined by using a Minolta colorimeter CR-200, through the system CIELAB. This was placed in three different points on the meat and the reading of the coordinates $L^{*}$ (luminosity), $r^{*}$ (red intensity) and $y^{*}$ (yellow intensity) was performed. The colorimeter was calibrated to a white standard, performing the evaluation $5 \mathrm{~min}$ after the muscle cutting, to expose the myoglobin to oxygen, according to Cañeque and Sañudo (2000).
The water holding capacity (WHC) was determined using subsamples of meat with an initial weight of $0.5 \mathrm{~g}$, being weighed on analytical balance and then placed between filter paper and acrylic plates, in which a weight of $10 \mathrm{~kg}$ was placed on the subsamples during $5 \mathrm{~min}$. The samples were weighed again to give the final weight according to the adapted methodology by Silva Sobrinho (1999), and then, the WRC was calculated according to the following equation: $\operatorname{WHC}(\%)=[($ final weight $(\mathrm{g}) \times 100) /$ initial weight of sample $(\mathrm{g})]$.

In relation to the losses by cooking (CL), fat drip (FDL), and evaporation (EL), these were determined by performing the initial weighing of the combined tray + grill and meat samples, separately. These were subsequently placed into an industrial oven with a temperature of $175{ }^{\circ} \mathrm{C}$, where the samples remained until the internal center temperature of the sample reached $75^{\circ} \mathrm{C}$, being measured using a digital thermometer skewer. After cooling, the group tray + grill with sample and the sample after cooking were weighed again, to calculate the values of cooking losses. As for the fat drip loss, the equation used was FDL $(\%)=[($ tray + grill with cooked sample - roasted sample) - tray + grill group weight] and for the evaporation loss, EL $(\%)=[($ raw sample - roasted sample $)+$ FDL $]$. After cooling and weighing of the baked samples, they were divided into cubes of $1 \mathrm{~cm}^{2}$ and placed on the Texture Analyzer device, coupled to the Warner-Bratzler device, in order to determine the shear strength force of the sample, being this measure provided in kilograms force per square centimeter $\left(\mathrm{kgf} / \mathrm{cm}^{2}\right)$.

The second portion of the longissimus lumborum muscle was led to the Animal Nutrition and Bromatology Laboratory of the Federal University of Vale do São Francisco. After defrosting, the samples were ground in a food processor and dried in a drying oven with forced circulation at a temperature of $55^{\circ} \mathrm{C}$ for $72 \mathrm{~h}$.

At the end of this process, the samples were ground in a ball mill for further analyses of humidity, crude protein, ether extract and mineral matter, according to the AOAC methodology (1995).

The results were analyzed using PROC GLM by the Statistical Analysis System computer program (SAS, version 9.12003 ), being previously checked the normality of the residues by the SHAPIROWILK test (PROC UNIVARIATE) and the removal outliers and the homogeneity of variances by the Levene test.

For quantitative and qualitative parameters of carcass and meat lamb, the statistical model: $Y i j=\mu+B i+T j+E i j$; where $\mu=$ the overall mean; $\mathrm{Bi}=$ block effect $(i=1$ to 8$)$, $\mathrm{Tj}=$ treatment effect $(\mathrm{j}=1$ to 4$)$; and $\mathrm{Eij}=$ residual error were used. All data were evaluated using orthogonal polynomials (linear and quadratic) with 5\% significance level.

\section{Results}

There was no difference $(P>0.05)$ for the parameters of body weight at slaughter, empty body, and cold and hot carcass, as 
well as for hot, cold, and true carcass yields of lamb receiving water with different salinity levels (Table 3 ).

No differences $(P>0.05)$ were observed between treatments for variables of temperature, color coordinates $\left(L^{*}, r^{*}\right.$, and $\left.y^{*}\right)$, as well as water retention capacity, losses by cooking, by dripping fat and evaporation, and shear force of Santa Inês lamb meat receiving water with different salinity levels (Table 4).

\section{Discussion}

According to data present in Table 3, the body weight at slaughter $(26.69 \mathrm{~kg})$, hot $(12.30 \mathrm{~kg})$ and cold $(12.00 \mathrm{~kg})$ carcass weight, hot $(46.10 \%)$, and cold $(44.98 \%)$ carcass yields are within the values observed by Paim et al. (2013) who found averages of $26.62,12.48$, and $12.07 \mathrm{~kg}$, and 47.00 and $45.00 \%$ for the respective variables in Santa Inês lambs.

It was observed an average value of $2.40 \%$ for loss by cooling. This value can be considered as normal, since Martins et al. (2000) state that, in the general, losses by cooling for lamb carcasses are about $2.5 \%$, and may oscillate from 1 to $7 \%$, depending on factors such as uniformity of fat cover, gender, weight, temperature, and relative humidity of the cooling chamber.

The average value of $56.70 \%$ observed for the biological yield of carcasses of Santa Inês lambs in this work can be

Table 3 Body weight at slaughter (BWS); empty body (EB); hot (HCW) and cold carcass weight (CCW); fasting loss (FL); hot (HCY), cold (CCY), and true (TY) carcass yields; losses by cooling (LC); and carcass (CCI) and leg (LCI) compactness index of Santa Inês lambs receiving water with different salinity levels

\begin{tabular}{|c|c|c|c|c|c|c|c|}
\hline \multirow[t]{2}{*}{ Parameter } & \multicolumn{4}{|c|}{ Treatments $^{\mathrm{a}}$} & \multirow[t]{2}{*}{$\mathrm{SE}^{\mathrm{b}}$} & \multicolumn{2}{|c|}{$P$ values* } \\
\hline & 640 & 3188 & 5740 & 8326 & & $L$ & $Q$ \\
\hline BWS (kg) & 27.2 & 25.2 & 27.8 & 26.5 & 0.56 & 0.9217 & 0.7838 \\
\hline EB (kg) & 22.0 & 20.5 & 22.2 & 21.8 & 0.44 & 0.7703 & 0.5854 \\
\hline HCW (kg) & 12.4 & 11.8 & 12.7 & 12.2 & 0.27 & 0.9005 & 0.8667 \\
\hline CCW (kg) & 12.1 & 11.5 & 12.4 & 12.0 & 0.27 & 0.7613 & 0.9098 \\
\hline FL $(\%)$ & 5.0 & 6.9 & 7.1 & 6.0 & 0.44 & 0.4235 & 0.1088 \\
\hline $\operatorname{HCY}(\%)$ & 45.8 & 46.8 & 45.6 & 46.3 & 0.37 & 0.9225 & 0.8342 \\
\hline $\mathrm{CCY}(\%)$ & 44.4 & 45.5 & 44.7 & 45.3 & 0.39 & 0.5731 & 0.7892 \\
\hline TY (\%) & 57.6 & 57.1 & 56.9 & 56.2 & 0.37 & 0.9225 & 0.8342 \\
\hline LC $(\%)$ & 3.0 & 2.7 & 1.9 & 2.0 & 0.43 & 0.3500 & 0.8395 \\
\hline CCI (kg/cm) & 0.2 & 0.2 & 0.2 & 0.2 & 0.005 & 0.8167 & 0.7014 \\
\hline LCI & 0.6 & 0.5 & 0.5 & 0.5 & 0.01 & 0.4555 & 0.3613 \\
\hline
\end{tabular}

* $P$ values, where $L=$ linear effect and $Q=$ quadratic effect

${ }^{\text {a }}$ Treatments: T1 $=640 \mathrm{mg}$ TSD in the water $(1 \mathrm{dS} / \mathrm{m})$; T2 $=3188 \mathrm{mg}$ TSD in the water $(5 \mathrm{dS} / \mathrm{m}) ; \mathrm{T} 3=5740 \mathrm{mg}$ TSD in the water $(9 \mathrm{dS} / \mathrm{m})$; and $\mathrm{T} 4=8326 \mathrm{mg}$ TSD in the water $(13 \mathrm{dS} / \mathrm{m})$

${ }^{\mathrm{b}}$ Standard error
Table 4 Lightness $\left(L^{*}\right)$, red intensity $\left(r^{*}\right)$, and yellow intensity $\left(y^{*}\right)$ values, water holding capacity (WHC), cooking losses (CL) by dripping fat (FDL) and evaporation (EL), shear force (SF), and chemical composition of the lamb meat receiving water with different salinity levels

\begin{tabular}{lrrrrrrrl}
\hline \multirow{2}{*}{ Parameter } & \multicolumn{3}{c}{ Treatments $^{\mathrm{a}}$} & & & \multirow{2}{*}{ SE $^{\mathrm{b}}$} & \multicolumn{2}{l}{$P$ values* } \\
\cline { 2 - 4 } \cline { 8 - 9 } & 640 & 3188 & 5740 & 8326 & & $L$ & $Q$ \\
\hline$L^{*}$ & 38.4 & 37.1 & 38.9 & 39.3 & 0.47 & 0.2918 & 0.3660 \\
$r^{*}$ & 14.8 & 13.8 & 13.6 & 12.2 & 0.46 & 0.0665 & 0.8613 \\
$y^{*}$ & 9.2 & 9.2 & 10.6 & 10.7 & 0.34 & 0.0690 & 0.9400 \\
WHC (\%) & 57.5 & 58.9 & 58.5 & 57.6 & 1.06 & 0.9837 & 0.6094 \\
CL (\%) & 30.4 & 33.5 & 30.9 & 30.2 & 1.23 & 0.7670 & 0.4585 \\
FDL(\%) & 8.6 & 11.2 & 7.4 & 6.9 & 0.97 & 0.3265 & 0.4373 \\
EL (\%) & 13.4 & 13.1 & 11.7 & 16.0 & 1.86 & 0.7159 & 0.5483 \\
SF (kgf/cm $\left.{ }^{2}\right)$ & 3.9 & 3.9 & 2.6 & 3.5 & 0.22 & 0.1414 & 0.2904 \\
Moisture & 73.8 & 74.2 & 73.8 & 72.7 & 0.22 & 0.0634 & 0.0746 \\
Crude protein & 23.3 & 22.8 & 22.9 & 22.1 & 0.23 & 0.0969 & 0.7251 \\
Ether extract & 2.2 & 2.4 & 2.6 & 2.8 & 0.12 & 0.0734 & 0.8747 \\
Mineral matter & 4.3 & 4.5 & 4.3 & 4.1 & 0.05 & 0.0884 & 0.1772 \\
\hline
\end{tabular}

*P values, where $L=$ linear effect and $Q=$ quadratic effect

${ }^{\mathrm{a}}$ Treatments: $\mathrm{T} 1=640 \mathrm{mg}$ TSD in the water $(1 \mathrm{dS} / \mathrm{m}) ; \mathrm{T} 2=3188 \mathrm{mg}$ TSD in the water $(5 \mathrm{dS} / \mathrm{m})$; T3 $=5740 \mathrm{mg}$ TSD in the water $(9 \mathrm{dS} / \mathrm{m})$; and $\mathrm{T} 4=8326 \mathrm{mg}$ TSD in the water $(13 \mathrm{dS} / \mathrm{m})$

${ }^{\mathrm{b}}$ Standard error

considered satisfactory for lamb carcass. Cunha et al. (2008) observed average value of $56.46 \%$, when evaluating when different levels of cottonseed were provided for Santa Inês lambs. When analyzing the average value obtained for the carcass compactness index $(0.25 \mathrm{~kg} / \mathrm{cm})$, it is observed similarity between these and those achieved by Cartaxo et al. (2009). It is observed a value of $0.23 \pm 0.02 \mathrm{~kg} / \mathrm{cm}$ in the carcass of Santa Inês lambs slaughtered with around $29.15 \mathrm{~kg}$.

The carcass compactness index observed in this study (0.25) indicated that animal carcasses that consumed water with high levels of salinity showed adequate muscularity distribution, assuming that such salinity levels were not a factor influencing the carcass conformation of lambs.

Average values obtained for lightness (38.46), red intensity (13.59) and yellow intensity (9.92) are among the values observed by Cañeque and Sañudo (2000) for lamb meat, when such values ranged from 30.03 to 49.47 for lightness $\left(L^{*}\right)$, from 8.24 to 23.53 for red intensity $\left(r^{*}\right)$, and from 3.38 to 11.10 for yellow intensity $\left(y^{*}\right)$.

In order to evaluate the meat quality of lambs fed with sorghum tolerant to salinity, Al- Khalasi et al. (2010) found average values of $L^{*}, r^{*}$, and $y^{*}$ equal to $31.9,13.4$, and 3.8, respectively, in the longissimus dorsi muscle of Omani lamb. It is known that nutrition presents great importance for production and general lamb characteristics (Madruga et al. 2005). It is observed that, even with ingestions of high levels of salinity 
through water, these seem not to cause influence on the meat color.

In relation to water holding capacity (WHC), meat of lambs receiving waters with different salinity levels had $58.12 \%$ of water holding, in accordance with the values obtained by Moreno et al. (2015) of $60.99 \%$ water retention in the muscle longissimus lumborum of Santa Inês lambs fed $30 \%$ of saltbush hay. The WHC can be influenced by diet, and the high salinity levels in the water ingested by the animals did not affect this characteristic.

As for the shear force, the average value found in this study was $3.50 \mathrm{kgf} / \mathrm{cm}^{2}$, higher than that observed by Fernandes et al. (2011) which was $2.28 \mathrm{kgf} / \mathrm{cm}^{2}$ and Moreno et al. (2015) with $2.58 \mathrm{kgf} / \mathrm{cm}^{2}$ for Santa Inês lamb meat. However, the difference between the values of these studies may be explained by difference in age between the animals from both studies, since the aforementioned authors evaluated the meat of animals with an average age of 5 months.

There was inferiority in the average values observed in this study for losses by cooking (31.26\%) and evaporation (13.57\%) and superiority for dripping fat loss (8.57\%) when compared with those values observed by Pinheiro et al. (2008). These authors found average values of $35.20 \%$ for cooking loss, $33.84 \%$ for evaporation loss, and $1.36 \%$ for fat drip loss when they rated the meat quality of one half Ile de France and one half Santa Inês lamb. However, such differences between the values observed in the above parameters can be attributed to the use of different muscles, when these authors used the triceps brachii muscle in their ratings.

The qualitative parameters of meat such as color (represented by $L^{*}, r^{*}$, and $\left.y^{*}\right)$, water holding capacity, cooking losses (including fat drip and evaporation losses), and shear force can be influenced by factors related to the animal as the inherent nutritional power. Since water is considered a nutrient, its chemical quality can be a factor influencing the qualitative parameters of meat, according to Markwick (2007), the salinity influences the water intake due to the need to regulate the balance of salts in the animal organism which could affect the development of the animal and thus the meat.

In this study, it was observed that even ingesting water with high salinity levels (5740 and $8326 \mathrm{mg}$ TDS/L water), the physicochemical parameters of meat did not show any differences between treatments, nor outliers when compared to other studies assessed, demonstrating that the sheep were able to adapt their systems to high levels of salt concentration $(\mathrm{NaCl})$ and did not affect their metabolic capacity.

Therefore, it is possible to suggest the existence of adaptive mechanism of the animals for such total dissolved solid concentration in the water, since, at certain periods of the year, when there is water scarcity by low rainfall, the water with high levels of salinity is the only resource available for the consumption of animals.
The average value obtained for moisture content was $73.62 \%$ (Table 4). This is below the average levels observed by Santos et al. (2009), with values of 79.58, 76.11, and $74.94 \%$ for meat of Santa Inês lambs receiving 0.0, 1.0, and $1.5 \%$ supplementation levels of finished and body weight on native pasture. However, it was similar to those observed by Madruga et al. (2005), when evaluating the effect of providing different diets for Santa Inês lambs, obtaining values between 70.81 and $76.07 \%$, showing the influence of diet on the qualitative parameters of the meat.

The average level of crude protein and mineral content of sheep meat receiving different levels of salinity in the water was 22.81 and $4.30 \%$, respectively. These values are higher than the values reported by Santos et al. (2008) and Santos et al. (2009), who obtained average values of $19.67 \%$ of crude protein and $0.95 \%$ of mineral matter for meat of Santa Inês lambs slaughtered at average weight of $25 \mathrm{~kg}$.

Because there are no differences between treatments in relation to the mineral content found in the meat evaluated, it is possible to suggest that the minerals ingested by the animals through the water were not deposited on the meat.

\section{Conclusion}

Water with salinity level of up to $8326 \mathrm{mg} / \mathrm{L}$ of total dissolved solids may be supplied for sheep, because they did not cause changes on the carcass characteristics and meat quality of the of Santa Inês lambs.

\section{Compliance with ethical standards}

Statement of animal rights All experimental procedures with animals were conducted in accordance with the ethical principles for animal testing adopted by the Committee on Ethics and Deontology Studies and Research at the Federal University of Vale do São Francisco. Protocol Number: 0007/131014.

Conflict of interest The authors declare that they have no conflict of interest. All co-authors participated in the execution of the research, in the writing of this article, and they agree with this final version.

\section{References}

Al- Khalasi, S.S.; Mahgoub, O.; Kadim, I.T.; Al-Marzooqi; Al-Rawahi, S.A. 2010. Salt tolerant fodder for Omani sheep (effects of salt tolerant sorghum on performance, carcass, meat quality and health of Omani sheep). A Monograph on Management of Salt-Affected Soils and Water for Sustainable Agriculture, 67-81.

AOAC. 1995. Official methods of analysis of the Association of Official Analytical Chemistry. 16th Ed., AOAC International, Washington, $1141 \mathrm{p}$.

Australian Water Association. In: Australian and New Zealand guidelines for fresh and marine water quality. Volume 1. The guidelines. Australian and New Zealand Environment and Conservation 
Council, Agriculture and Resource Management Council of Australia and New Zealand. 2000. http://www.environment.gov. au/system/files/resources/53cda9ea-7ec2-af29-d1dde09e96ef/files/ nwqms-guidelines-4-vol1.pdf. Accessed 15 fev 2012.

Agência Nacional de Águas - ANA. In Atlas Brasil: Abastecimento urbano de água: Panorama Nacional. Volume 1. Agência Nacional de Águas. Engecorps/ Cobrape - Brasília 2010. http://atlas.ana.gov. $\mathrm{br} /$ Atlas/downloads/atlas/Resumo\%20Executivo/Atlas\%20Brasil\% 20-\%20Volume\%201\%20-\%20Panorama\%20Nacional.pdf. Accessed 17 fev 2012.

Cañeque, V.; Sañudo, C. 2000. Metodologia para el estúdio de la calidad de la canal y de la carne en rumiantes. Madrid: Instituto Nacional de Investigación y Tecnologia y Alimenticia, 255p.

Cartaxo, F. Q.; Cezar, M. F.; Sousa, W. H.; Gonzaga Neto, S.; Pereira Filho, J. M.; Cunha, M. G. G. 2009. Quantitative traits of carcass from lambs finished in feedlot system and slaughtered at different body conditions, Brazilian Journal of Animal Science, 38, 697-704.

Colacelli, N. A. In: Calidad de agua para bebida animal. 1997. http <www.produccion.com.ar/1997/97abr_11.htm>. Accessed 18 set. 2012.

Colomer-Rocher, F.; Morand-Fehr, P.; Kirton, A.H. 1987. Standard methods and procedures for goat carcass evaluation, jointing and tissue separation. Livestock Production Science, 17, 149-159.

CPRM - Companhia de Pesquisa de Recursos Minerais. Serviço Geológico do Brasil. 2012. http://www.cprm.gov.br/publique/cgi/ cgilua.exe/sys/start.htm?sid=35. Accessed 23 fev 2012.

Cunha, M. G. G.; Carvalho, F. F. R.; Gonzaga Neto, S.; Cezar, M. F. 2008. Effect of feeding whole cottonseed levels on carcass quantitative characteristics of feedlot Santa Inez sheep, Brazilian Journal of Animal Science, 37, 1112-1120.

Fernandes, A. R. M.; Orrico Junior, M. A. P.; Orrico, A. C. M.; Vargas Junior, F. M.; Oliveira, A. B. M. 2011. Performance and qualitative characteristics of carcasses and meat of lambs finished in confinement and fed diets containing soybean grain or protected fat, Brazilian Journal of Animal Science, 40, 1822-1829.

Madruga, M. S.; Sousa, W. H.; Rosales, M. D.; Cunha, M. G. G.; Ramos, J. L. F. 2005. Qualidade da carne de cordeiros Santa Inês terminados com diferentes dietas. Revista Brasileira de Zootecnia, 34, 309-315.
Martins, R.R.C.; Oliveira, N. M.; Osorio, J.C.S.; Osório, M. T. M. 2000. Peso vivo ao abate como indicador do peso e das características quantitativas e qualitativas das carcaças em ovinos jovens da raça Ideal. Bagé: Embrapa Pecuária Sul, 29p. (Boletim de Pesquisa, 21).

Moreno, G.M.B.; Borba H.; Araújo, G.G.L.; Sañudo, C.; Silva Sobrinho, A.G.; Buzanskas, M.E.; Lima Júnior, D.M; Almeida, V.V.S.; Boaventura Neto, O. 2015. Meat quality of lambs fed different saltbush hay (Atriplex numulária) levels. Italian Journal of Animal Science, 14, 251-259.

Markwick, G. 2007. Water requirements for sheep and cattle. Profitable \& Sustainable primary industry.

National Research Council-NRC. 2007. Nutrient requirements of small ruminants: sheep, goats, cervids, and new world camelids. Washington, D.C., 384 p.

Paim, T.P.; Silva, A.F.; Martins, R.F.S.; Borges, B.O.; Lima, P.M.T.; Cardoso, C.C.; Esteves, G.I.F.; Louvandini, H.; McManus, C. 2013. Performance, survivability and carcass traits of crossbred lambs from five paternal breeds with local hair breed Santa Inês ewes. Small Ruminant Research, 112, 28-34.

Pinheiro, R. S. B.; Jorge, A. M.; Francisco, C. L.; Andrade, E. N. 2008. Composição química e rendimento da carne ovina in natura $\mathrm{e}$ assada. Ciência e Tecnologia de Alimentos, 28, 154-157.

SAS, 2003. Statistical analysis system. User's guide, version 9.1 SAS Institute (INC. Cary. NC. USA)

Santos, C. L.; Perez, J. R. O.; Cruz, C. A. C.; Muniz, J. A.; Santos, I. P. A.; Almeida, T. R. V. 2008. Análise centesimal dos cortes da carcaça de cordeiros Santa Inês e Bergamácia. Ciência e Tecnologia de Alimentos, 28, 51-59.

Santos, J. R. S.; Pereira Filho, J. M.; Silva, A. M. A.; Cezar, M. F.; Borburema, J. B.; Silva, J. O. R. 2009. Tissue and chemical composition of commercial cuts of carcasses of Santa Inês lambs finished on native pasture with different supplementation levels, Brazilian Journal of Animal Science 38, 2499-2505.

Silva Sobrinho, A.G. 1999. Body composition and characteristics of carcass from lambs of different genotypes and ages at slaughter, (Post Doctorate in Sheep Meat Production, Massey University, Palmerston North). 